\title{
The Double Register of History: Situating the Forgotten Woman and Her Household in Capitalist Commodity Chains
}

Wilma A. Dunaway

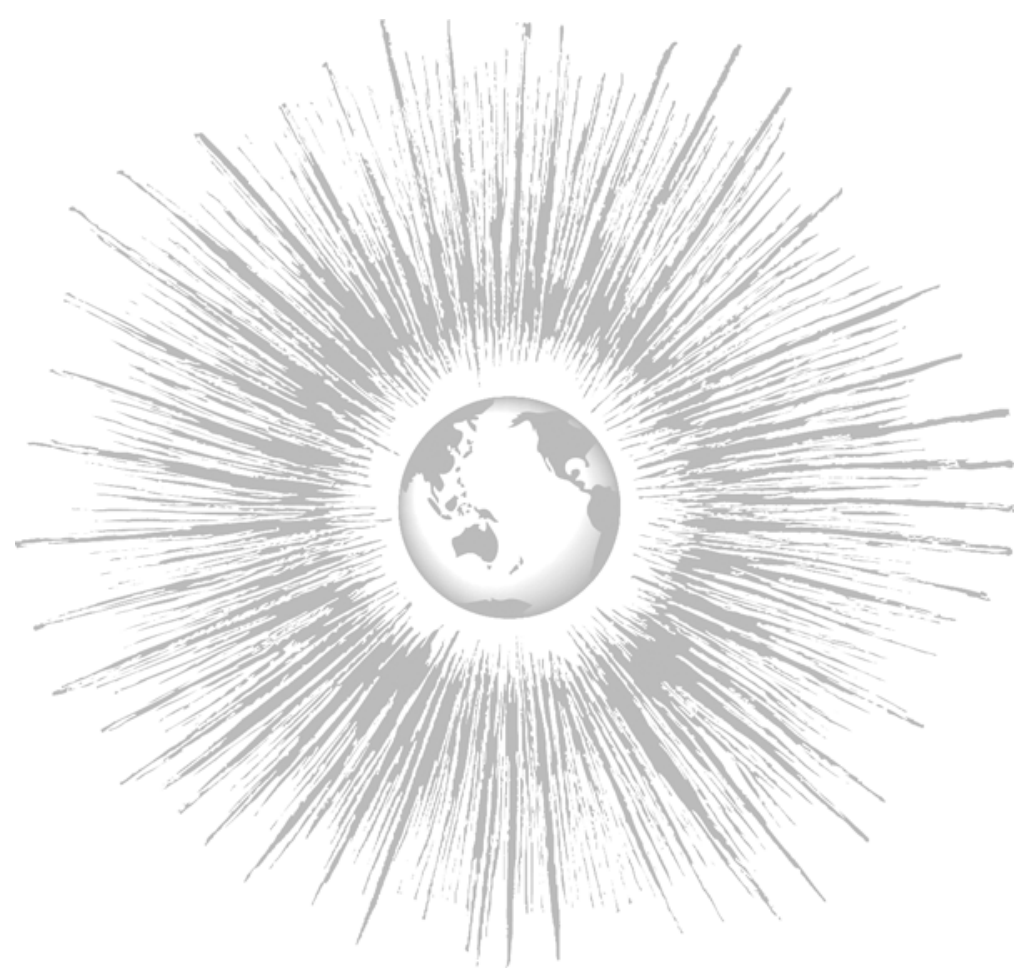

\section{THE STATE OF THE FIELD}

By analyzing research and theoretical foci in its three major publication venues, we can judge how much attention the world-system perspective has been paying to women. ${ }^{1}$ After 25 years, women are only a faint ghost in the world-system perspective. In the first twenty volumes of Review, less than 5 percent (16) of the articles deal with gendered exploitation, women, or households. In the first five volumes of the Journal of World-System Research, less than 4 percent of the articles address women's issues. ${ }^{2}$ By 1999, PEWS had published 21 annual monographs; yet less than 5 percent of the articles in those volumes integrated women or gender inequities. ${ }^{3}$ Another indicator of women's invisibility is that relevant terms about gender

Wilma A. Dunaway

Department of Sociology

Virginia Tech University

560 McBryde Hall

Blacksburg, VA 24061-0137

wdunaway@vt.edu

http://www.cas.vt.edu/sociology/

* I would like to thank Don Clelland for his critical comments and his bibliographical assistance through several drafts of this article.

1. I analyzed the content of Review, volumes 1 through 20, the Journal of World-System Research, volumes 1 through 5 (Nos. 1-3), and the monographs that have been published as PEWS annuals. For a complete list of the PEWS annuals, see $<$ http:// fbc.binghamton.edu/pews.htm $>$.

2. Only four articles address women's issues (Moon 1997; Dickinson 1998; Moghadam 1999; Smith 1999). However, two of these articles offer no explanations from the worldsystem vantage point and make no references to world-system literature. Moon (1997) is positive toward women in development approaches with which the world-system 
or household are listed in only two of the indexes of these PEWS annuals. Overall, women, households, and gender inequities were investigated by less than 5 percent of all the studies that appear in the three major venues of world-system publication. In short, women's problems still lie far out at the distant periphery of the field.

Our track record is even worse than these statistics reveal. Even in research that claims to focus on households, we have made less than a minimalist effort to connect the capitalist restructuring of women's everyday lives with other transformations that occur in the world-system. In the articles that focus on households, for example, fewer than 50 percent actually include either of the terms women, female, or gender inequity. Even when world-system analysts address issues that are central to women's lives, they have forgotten the suppression and exploitation of females almost entirely. In a majority of the studies of agricultural households that appear in these three publication venues, the words women or female rarely appear, and there is very limited analysis of gender differences among agricultural laborers or households. This oversight occurs in the face of the historical reality that women have always comprised a large segment of the agricultural labor force, a conceptual error that is common in the mainstream literature against which we purport to argue. ${ }^{4}$ We have managed to talk about plantations, peasant households, the informal sector, and labor unrest without ever mentioning women or gender disparities. ${ }^{5}$ Our analysis of commodity chains (Hopkins and Wallerstein 1986, 1994; Gereffi

perspective disagrees. Though she examines only wage earners, Miller (1999) repeatedly employs the phrase "women's share of the labor force." Her careless choice of sexist wording is the equivalent of saying to a nonwaged mother of children: "why don't you work?" (Waring 1988: 22).

3. The Political Economy of the World-System Section (PEWS) has never highlighted the exploitation of women for its annual conference theme, but the 1987 conference focused on the two vast topics of racism and sexism. The articles published in PEWS annuals are Truelove (1987); seven articles in Smith, Collins, Hopkins, and Muhammad (1988); Collins (1995); Matthei and Smith (1996).

4. In its special issue about agricultural households, Review (vol. 7, no. 2), published only 1 article (von Werlhof 1983) that analyzes gender inequality. The word women rarely appears in the other 4 articles of that issue. The PEWS annual dealing with agriculture and food systems includes only one article (Collins 1995) that analyzes gender inequality, and there are only ten brief mentions of women in its 275 pages.

5or studies that inappropriately ignore females in economic activities that routinely employ waged women, see Stauth (1983); Thompson (1991); Petrusewicz (1987). Regarding the informal sector, contrast Portes (1983) with Smith, Collins, Hopkins, and Muhammad (1988: 24-27)
The Double Register of History

and Korzeniewicz 1994) leaves readers with the impression that no households or no women exist in the nodes or the networks that comprise those complex mechanisms. Women have rarely made the pages when we have constructed explanations of incorporation or the emergence of a capitalist labor force (Wallerstein and Martin 1979; Hopkins and Wallerstein 1987). There is a trend toward the rapid entry of peripheral women into wage labor jobs and a worldwide trend toward deepening feminization of poverty (United Nations 1999). Still impacts on women were not examined in a recent analysis (Smith and Borocz 1995) of the global transformations of the late 20th century. Like women, the environment has received inadequate attention in world-systems analyses; but those aligned with the perspective have shown a commitment to correct that deficiency through the blossoming of publication in recent years. However, women are also missing from these recent world-system analyses of ecological degradation. ${ }^{6}$

Even when the role of women should come automatically to our minds as we think and write about topics, we have left them out. Despite the vast literature about the unpaid labor of women as a primary mechanism in the maintenance of laborer households, the tendency in world-system analyses is to speak about the reproduction of laborer households as though these entities are ungendered. ${ }^{7}$ Even though there have been ground-breaking analyses (e.g., Ward, 1982, 1985) of how the world-economy structures the interconnected cycles of high child mortality and high fertility, most world-system analysts forget the biological reproductive role of women. We have also analyzed the household economy, subsistence production, and handicrafts production - the very domestic domains of women-without acknowledging the inputs of females, often without mentioning women at all. ${ }^{8}$ Trends over the last three decades show that peripheral girls suffer a higher incidence of chronic hunger than males (United Nations 1999), yet world-system analysts have examined malnutrition in poor countries without seeing the gender inequities in the food supply. ${ }^{9}$ World-system analysts have been guilty of an enormous condescension toward women; for questions about females, households, and

6. For world-system analyses of the environment, see Journal of World-System Research (vol. 3, no. 3) and Goldfrank, Goodman, and Szasz (1999).

For analyses of household reproduction that ignore women, see Stauth (1983); Frobel (1982); Thompson (1991). Ulshofer (1983: 189) claims that "reproduction is wholly dependent on external relations to the capitalist factor markets."

8. For studies that ignore women's domestic production, see McCann (1986); Feder (1980); Quataert (1988).

9. For studies of malnutrition that ignore women, see Feder (1980); Micah (1989); McMichael (1995: 15-34). 
sexism are routinely ignored by the perspective's writers. In addition, world-system analysts have tended to disregard the work of radical feminists, even when those writers embrace a world-system conceptualization of capitalism (e.g., Mies 1982; Mies, Bennhold-Thomsen, and von Werlhof 1988) or employ very similar concepts (e.g., Nash and Fernandez-Kelly 1983; Beneria and Roldan 1987; Salleh 1994). To use a metaphor from Dorothy Smith, the world-system perspective has not yet reached the level of "add women and stir" that characterized so many disciplines in the 1980s. What is the real danger of this void? The gender blindness of the world-system perspective sends the political message to women all over the world that we do not consider the problems of their lives worth knowing or worth telling. Through this intellectual and political blunder, we have, by default, relinquished women to the enemy. In the same time period that the world-system perspective has been ignoring gender inequality, the pro-capitalist development paradigms have discovered women and are attempting to co-opt them all over the world. By making the intellectual choices we have about gender, we convince female scholars and activists that world-system analysis is irrelevant to their concerns. In effect, then, we have disconnected our research agenda and our praxis from more than half the world's population and from a majority of the wretched of the earth.

What have been our successes in the analysis of women's exploitation? Wallerstein has played a pivotal role in laying the groundwork for three constructs that hold promise for the analysis of gender inequality: household, semiproletariat, and commodity chain ${ }^{10}$ However, most world-system analysts either ignore these crucial ideas, or they utilize them in ways that exclude questions about women. I am convinced that these three important concepts offer us the tools we need to rescue women from the periphery of world-system thought. Consequently, this article will suggest the kinds of theoretical issues we need to raise if we are to engender worldsystem analyses. Second, I will specify the conceptual blunders that cause us to overlook the gendered implications of the structural transformations that we study. Third, I will propose a synthesis of ideas from radical feminism with the worldsystems notions of the semiproletarianized household and the commodity chain. Along the way, I will direct attention to major global trends of gender inequality at the end of the twentieth century.

10. For the conceptualization of households and semiproletariat, see Wallerstein and Martin (1979); von Werlhof (1980); Wallerstein (1983); Wallerstein, Martin and Dickinson (1982); Smith, Wallerstein, and Evers (1984); McGuire, Smith, and Martin (1986); Smith and Wallerstein (1992: 3-26, 253-62). For conceptualization of the commodity chain, see Hopkins and Wallerstein $(1986,1994)$.
ENGENDERING THE CONCEPT OF HOUSEHOLDS

According to Wallerstein, the capitalist world-system has structured a controlling mechanism by which the demands of workers for increased compensation can be restrained. That mechanism the semiproletarian household, is now the dominant mode worldwide. "In such households, the wages paid to those members engaging in wage-labor activities can be reduced below the level of household reproduction because the household supplements this income with its other income-generating activities..., the totality of which bring in a greater income per hour of work than does wage-labor" (Wallerstein, 1995: 5-6). ${ }^{11}$ Despite the centrality of this concept in Wallerstein's work, the semiproletarian household has only rarely been recognized as a central element in the research agendas of world-system analysts. Even in the theoretical groundwork of Wallerstein and several research panels at the Fernand Braudel Center (Smith, Wallerstein, and Evers 1984; Smith and Wallerstein 1992), the tendency of the perspective has been to conceptualize households as though they are not gendered entities in which women play pivotal roles. In the three worldsystem publication venues, only seven of the articles that investigate households actually analyze women and/or gender inequality. ${ }^{12}$ The typical pattern has been that world-system analysts explore household transformation without ever employing the terms women or gender inequality. ${ }^{13}$ Because the perspective has virtually erased gender from households, it is essential that we rethink world-system notions (Ward 1993). ${ }^{14}$ According to Smith and Wallerstein (1992: 19-21), three structural forces determine the boundaries and internal dynamics of households: (a) the cycles

11. The centrality of the semiproletariat has been stressed by Wallerstein (1976) for more than two decades. Still, this concept has only rarely been recognized as a central element in the research agendas of world-system analysts.

12. These articles about households also analyze women and/or gender inequality: Turner and Benjamin (1995); McGuire, Smith and Martin (1986); Ward (1985); Vellenga (1985); Wallerstein, Martin, and Dickinson (1982); von Werlhof (1980); Morrissey (1986).

13. These studies analyze households without ever mentioning women: Thompson (1991); Ulshofer (1983); Stauth (1983); Fox-Genovese (1983); Meyers (1983); Wallerstein and Martin (1979); Elwert and Wong (1980); McCann (1986).

14. In his historical retrospective about the world-system perspective, Martin (1994: 163) describes the difficulties encountered in the theoretical formulation of household boundaries, suggesting that this problem was never satisfactorily resolved. For conceptual problems of ethnocentrism and household boundaries, see Vellenga (1985); Thompson (1991); Smith and Wallerstein (1992: 13-14). 
and trends of the world-economy, (b) state machinery, and (c) ethnicity/culture/ subculture. Why did gender disappear in this unrealistic fashion? Obviously, we need to rethink this concept so that we do not make women invisible in this manner. If we are to engender the household, we must begin with a re-examination of income pooling. Smith and Wallerstein (1992: 15) have defined a household as "a unit that pools income for purposes of reproduction," and they have linked this notion to the semiproletarianization of women. "Stagnations in the world-economy create pressures on small household structures to enlarge boundaries and to self-exploit more....For a wage worker in a semi-proletarian household is more able to accept a low real wage since this worker may be able to assume that, via self-exploitation, other compensating forms of income will be available" (Smith and Wallerstein 1992: 15-16). To subsidize the low and unstable wages of its members, the household pools four types of nonwage income: market sales, rent, transfer payments, and subsistence. ${ }^{15}$

As Wallerstein (1983) has argued, most of the world's households acquire only a minority of their survival needs from wages. It is imperative, therefore, that we select terminology that reflects our knowledge of the historical fact that nonwage and unpaid labor is the pivotal thesis of the world-systems model of households (Smith, Wallerstein, and Evers 1984; Smith and Wallerstein 1992). ${ }^{16}$ In contradiction to that central idea, the term income pooling implies the aggregation of money and of items to which a market price has been assigned. I prefer to think of households as resource pooling units, in order to encompass all sorts of women's economic and nonmaterial activities that are not implied by the list of four types of nonwage income. ${ }^{17}$ For example, the list of five categories of "income" offered by Smith and Wallerstein (1992) does not alert researchers to take into account inputs like garbage-picking,

15. Each of these categories is complex and not as simple as the term may imply; see Smith and Wallerstein (1992: 7-12) for explication. Their categories exclude three additional forms of household provisioning: reciprocal exchange of labor and resources, gifts (Polanyi 1957), and theft (Dunaway 2001: Chapter 6).

16. In his historical retrospective about the world-system perspective, Martin (1994: 163) describes the difficulties encountered in trying to relate non-wage to wage forms of labor within households and commodity chains. "This effort bristled with complications, requiring the specification in different locales and times of the gendered and generational antinomies of household relationships, the configuration of labor and commodity production within the boundaries of the household, and the reproduction of labor through pooling of resources derived from wage and non-waged labor."

17. Martin (1994: 163) also suggested the language shift to "pooling of resources." fuelwood gathering, or water collection. Households are not just producers and consumers. They are also units of reproduction; they are decision-making and resource-allocating units; they are sometimes economic enterprises that produce market commodities; they are arenas that transmit culture and ethnic heritage; and they are units that support and/or organize antisystemic resistance (Ulshofer, 1983: 192; Dunaway 1995, 1997, 2001; Hall 2000: 195-236). Furthermore, households pool many resources that are not material. For example, the first resource that a woman brings to her household is her own body which naturally reproduces human life, feeds infants, and is the object of sexual gratification. Nor does the notion of income pooling call attention to the non-material resources brought to households by women, such as care-giving or specialized eco-medical knowledge (Mies, Bennhold-Thomsen, and von Werlhof 1988).

The third conceptual weakness is that the world-system approach masks the power struggles and inequities within households. Indeed, the tendency of worldsystem analysts has been to beg off this issue. After laying considerable groundwork about the external processes that shape households, Wallerstein and Martin (1979: 202) apologetically commented in 1979: "What remain much less known are the actual dimensions of the reorganization of internal household dynamics." In the early 1990s after several radical studies of household inequities had appeared (e.g., Beneria and Roldan 1987), writers of the second world-system monograph on households (Smith and Wallerstein 1992: 12), were still excusing their failure to address "the internal structure of the households, and how power and goods are distributed internally." In short, the perspective admits that resource allocation is inequitable (McGuire, Smith, and Martin, 1986: 76-77), but we have not prioritized that household reality in our theory or our research. Because it ignores such inequities, the perspective has transformed women into appendages of households, thereby effectively erasing them from the world-system (Vellenga, 1985: 316). We need to stop depicting households as though they are ungendered monoliths. To do that, we must assess the true extent to which capitalism exploits the nonwaged labor of women. We cannot make such an inquiry unless we decompose household pooling strategies and recognize internal inequities.

Within the different contexts of pool and housekeeping allowance groups, women's capacity to maneuver the duty component of their total workload is very limited.... They can mobilise claims to other women's labor. In no case, however, have women been able significantly to diminish their own contribution by having husbands (or other male relatives) undertake a share of domestic work.... Men's [pooling] strategies involve collective and individual components; the women's, closely linked to the present and future situation of children, tend towards an overall, collective character (Beneria and Roldan 1987: 135-36). 
ENGENDERING THE CONCEPT OF COMMODITY CHAINS

In addition to the semiproletarian household, world-system analysis has advanced the concept of commodity chain. Hopkins and Wallerstein (1986: 159) envisioned a commodity chain to be "a network of labor and production processes whose end result is a finished commodity," every box or node in the chain representing "a particular, quite specific production process." World-system analysts have identified input acquisition, manufacturing, distribution, marketing, and consumption as the sequential stages of a commodity chain (Gereffi and Korzeniewicz 1994: 51, 2). Hopkins and Wallerstein $(1986: 162)$ stress that there are four properties for each node of a commodity chain: (a) the relations of production within the node, (b) organization of production, (c) the node's geographical location within the chain, and (d) flows between the node, other nodes of the chain, and with other commodity chains. A single commodity chain usually exploits several forms of waged and nonwaged labor. At the world-market level,"the uneven exchange of these commodities between nations... constitutes the very essences of global inequality" (Korzeniewicz and Martin 1994: 83). Thus, commodity chains are the key structural mechanisms of unequal exchange. They are the chains of the capitalist world-system in three senses: they derive from the system; they link together the diverse local economies of the system; and they entrap and exploit its entire population, almost no household excepted.

Personally, I am convinced that the commodity chain concept is one of the most promising tools through which world-systems analysis can integrate women and households. By examining commodity chains, we can do the type of research that Braudel (1981:28) loved; we can simultaneously overlay the "double register" of history: the global and the local. For Braudel (1981: 559, 29), history was the unveiling of "a succession of landscapes" consisting of two major levels of human existence: (a) the realm of major historical events and (b) "the ground floor and the first story" of history that lay in "images of daily life." Braudel (1979: 28-29, 16) argued that the task of the historian is to reveal the dialectical interplay between the upper and lower levels. But he complained that the lower level is too often ignored, so that everyday life has been "the great absentee in history" (Braudel 1979: 16).

Everyday life is also the "great absentee" from most commodity chain analyses. In some ways, our mechanistic applications of the model have done the work of mainstream economists better than they do it themselves. When a commodity chain is delineated in terms of "the production process itself" (Hopkins and Wallerstein 1986), it documents the construction or creation of a market product, overlooking far too many human and ecological aspects. In other words, it becomes an analysis that emphasizes things rather than human beings, exactly opposite to the historical approach urged by Braudel. ${ }^{18}$ What do we miss when we turn the analytic lens upon the commodity itself? First, a narrow emphasis upon those waged and nonwaged laborers who are involved directly in manufacture of the commodity can ignore three types of hidden laborer inputs. There can be direct and indirect flows into the production process from subsistence sectors, from the informal economy and from illegal sectors (Dunaway 1995). Second, the focus upon a particular commodity may unintentionally hide from view those laborers and resources in the interconnected local and distant commodity chains that supply the foodstuffs, raw materials and consumer goods to provision the production process (Dunaway 1996).

Third, commodity chain analysts have not recognized the pivotal role of households or of the females in those households. ${ }^{19}$ Consider Wallerstein's (1995: 6-7) description, for example.

Commodity chains have been the integument of capitalist production processes from the outset.... It is not hard to demonstrate that almost every item that is marketed by enterprises is constructed from components (which are in turn constructed from components), utilizing machinery (constructed in turn from components...) and manpower (sustained by food production constructed from components...), the totality of which are produced in geographically dispersed areas.

Hopkins and Wallerstein (1994: 50) have emphasized that commodity chains "reproduce a basic order that permits the endless accumulation of capital." Then they prioritize the research question they consider to be most crucial: "If one thinks of the entire chain as having a total amount of surplus value that has been appropriated, what is the division of this surplus value among the boxes of the chain?" What is missing? While the inequitable accumulation of capital at the world level is an important element of commodity chain analysis, it is only half of Braudel's (1981: 28) "double register" of history. At the macrostructural level, a commodity chain is indeed the global mechanism that insures the inequitable division of surplus among the core, semiperiphery, and periphery (Korzeniewicz and Martin 1994). Long before those expropriations can occur, however, the commodity chain structures the maximal exploitation of underpaid and unpaid labor. If we are to engender the commodity chain, we must also investigate how and by whom that surplus is produced at every node of the network. To accomplish this task, we must enter through the doorway of the household. It is

18. According to Braudel (1972, vol. 1: 353), the correct subjects for historical materialism are "human beings, and not 'things."

19. Gereffi and Korzeniewicz (1994: 12) acknowledge this weakness. 
beyond this portal that we find the forgotten woman, and we will find her working longer hours than men to contribute surpluses that do not appear in the account books of the capitalist enterprise or in the government's tally of the Gross National Product (Waring 1988).

According to Polanyi (1957: 43-55), the economy is submerged in the total social structure. ${ }^{20}$ In contrast, world-systems analysts have disembedded the commodity chain from its social underpinnings and from its ecological surroundings. Why have we forgotten that commodity chains are embedded in households and that the survival of those households rests inequitably on the shoulders of women? I am convinced that we lose the conceptual power of the commodity chain and the semiproletarianized household, unless we turn the conceptual lens a different direction. A commodity chain is more than a long string of spatial points at which mechanical processes occur to generate a marketable product. We need to re-embed commodity chains in the everyday lives of the laborer households at every node in the chain. We must think of the commodity chain first and foremost as an interconnected network of nodes at which human laborers and natural resources are (a) directly exploited and/or (b) indirectly exploited (c) to permit surplus extraction by a few.

Because they embed the commodity chain in material and mechanistic inputs, Hopkins and Wallerstein $(1986,1994)$ have de-emphasized the very concept that Wallerstein $(1983,1995)$ identifies as central to the world-system: the semiproletarian housebold. Indeed, they ignore the reality that every node of every commodity chain is embedded in the gendered relations of households. A commodity chain investigation should not focus solely on the material aspects of the commodity itself. Indeed, it is clear that Wallerstein (1983:32) knows that commodity chain analysis should be about the agenda of documenting the exploitation of semiproletarianized households. For he tells us in Historical Capitalism that commodity chains create and transform the household structures that permit the survival of low-paid workers. Consequently, the theoretical model of commodity chains needs to be extended to encompass these five key research questions that it did not originally address.

1. How does the commodity chain transform and reshape households through surplus extraction and unequal exchange?

2. To what degree do households and women subsidize the production process through non-wage inputs?

20. According to Polanyi (1957: 46), "Neither the process of production nor that of distribution is linked to specific economic interests attached to the possession of goods; but every single step in that process is geared toward a number of social interests.... the economic system will be run on noneconomic motives."
3. To what degree does the commodity chain externalize material, political, social and ecological costs to households and to women?

4. To what degree do households and women at lower nodes of the commodity chain subsidize households, laborers, or consumers at higher nodes?

5. To what degree does the commodity chain structure gender inequality within and among the households that comprise its entire labor force?

A commodity chain is a much more powerful conceptual tool when it is viewed as successive layers of unequal exchanges. ${ }^{21}$ Indeed, every exchange within a commodity chain is unequal, for there is a polarized distribution of the means of production (including natural resources) not only between nodes but also within every single node. If we turn our theoretical lens this direction, we can utilize the commodity chain to make visible "the basic inequality of partners that underlies the capitalistic process" and that permeates every aspect of social life (Braudel 1979: 62-63). World-system analyses have not only failed to integrate the labor and ecological contributions of households. They have also ignored the unequal exchanges that occur within households themselves. Used more effectively, the commodity chain approach can demonstrate that every node of the production process-and every household that contributes labor and resources to that node-are microcosms of the structural inequities of the capitalist world-system. "Men are simultaneously agents for capital and for themselves, keeping women intimidated and pliable" (Salleh 1994: 114). Consequently, women and girls contribute more labor power to household survival than males; but they receive an inequitable share of the total pool of resources (Mies, Bennhold-Thomsen, and von Werlhof 1988). Moreover, we would be able to see resistance against capitalist oppression as a process that is not monolithic. Within nonwestern households, women and men frequently conflict over the allocation of ecological resources. When capitalist incorporation creates new wage and trade opportunities for males, those economic activities quite often threaten the ecological resources from which women produce household sustenance and trade commodities (Dunaway 1997; Shiva 1988).

21. In a rare study that engenders the commodity chain, Vellenga (1985: 315) argues that the world-system notion of household is less useful than the concept of commodity chain to investigate women's invisible work. She states: "It is the concept of commodity chain that seems more helpful in looking at the way in which women operate as economic actors and at the way in which class differences emerge among women." 
WOMEN'S HIDDEN INPUTS INTO COMMODITY CHAINS

As it incorporates new zones of the globe, capitalism embraces two dialectical labor recruitment mechanisms. Some household members are proletarianized into wage laborers who produce capitalist commodities, but women's labor is concentrated into semiproletarianized activities that are only partially remunerated (Hopkins and Wallerstein 1987). Women's inputs into commodity chains occur at three levels. Historically, women have been wage laborers just as long as there has been capitalism (Dunaway 1995); and the late 20th century is characterized by two varied trends. ${ }^{22}$ In the core, most women are employed outside their homes, and that wage labor has altered household patterns and contributed to the high divorce rates. Nearly half of all wage-earning women work different hours than their spouses or partners, and two-fifths of all U.S. working women head their own households. ${ }^{23}$ At the periphery, women are increasingly entering the wage labor force (Ward 1990), but these poor women much more often subsidize commodity chains through low-paid, non-wage direct inputs (such as industrial homework) into the production process (Beneria and Roldan 1987). Historically, women have completed piece-rate labor through cottage industries and putting out systems. Their household-based labor generates market commodities or informal sector inputs into the export production process, but their labor has typically remained socially invisible, and they have received below-market prices for those contributions (Mies 1982). In tenant and sharecropping households, women's labor remains hidden behind that of adult males who execute contracts for the entire household with landholders (Mies, Bennhold-Thomsen, and von Werlhof 1988; Dunaway 1995). In the late 20th century, these forms of non-wage labor are still common all over the world (Mies 1982; Nash and Fernandez-Kelly 1983; Beneria and Roldan 1987; Ward 1990; Miller 1999). In the core, there is a trend toward home-based workers who utilize computers and subcontracting systems in which women are paid by task completion, thereby cutting the costs incurred by employers for wages and employee benefits (Hayashi 1998). In peripheral regions, women engage in industrial homework and make other

22. World-system analysts have done a fairly decent job of documenting women wage laborers, but they have done a poor job of documenting women's direct non-wage inputs into commodity chains. Moreover, world-systems analysts deny the material inputs of women into commodity chains when they carelessly employ sexist language like "manpower" to describe labor inputs (Wallerstein, 1995: 6). For studies that fail to document the nonwage inputs of women into commodity production, see Bergquist (1984: 108-34); Gereffi and Korzeniewicz (1994: 165-86); Smith and Borocz (1995: 91-108, 131-44).

23. AFL-CIO study released 9 March 2000; see <http://www.workingfamilies.com>. types of household-based inputs into commodity chains, including the collection of ecological resources and the retrieval of recyclable items from the garbage. In the late $20^{\text {th }}$ century, textile commodity chains are increasingly decentralized into puttingout systems in which household-based women finish commodities on a piece-rate basis (Mies 1982).

In addition to their direct wage and non-wage inputs, women and households subsidize the commodity chain through several forms of invisible labor and hardship. Destruction of precapitalist modes of production leads to a new sexual division of labor organized into semiproletarianized households (Smith, Wallerstein, and Evers 1984). In order to keep the waged labor force:

at a relatively low level of pay (by the existing standards of the world-economy), they had to be located in household structures in which the work on this new "export-oriented activity" formed only a small part of the lifetime revenues.... In this case, other household activities which brought in revenues in multiple forms could "subsidize" the remuneration for the "export-oriented activity," thereby keeping the labor costs very low (Hopkins and Wallerstein 1987: 777).

Consequently, the world-system transforms women into "the last link in a chain of exploitation, permitting by their unpaid labour the reproduction" of the work force and the unrewarded subsidization of male-dominated labor (Mies, BennholdThomsen, and von Werholf 1988: 29). What, then, are the hidden inputs of women and households into capitalist commodity chains (see Figure 1)? Households subsidize at three levels the commodity chains in which those laborers are situated. First, the biological reality of women's lives is sexual and reproductive; thus, mothers make their first subsidy to capitalism through the bearing and raising of successive generations of laborers. Despite its dependency upon this natural female contribution, however, capitalism has externalized laborer reproduction outside the realm of the economic. Thus, capitalism devalues women's childrearing as "a nuisance to the production unit" (Sen 1980:82). ${ }^{24}$ Second, the household is the site in which women undertake unpaid labor for those members who are waged laborers. By keeping production costs lower, women's hidden inputs subsidize the production process throughout the commodity chain, thereby keeping consumer prices lower and profits higher. To generate family survival requirements, women engage in

24. "What women do 'gratis,' whether birthing labor or sustaining labor, is called 'reproduction' as opposed to production. Yet the word reproduce here connotes a secondary or diminutive activity, as distinct from the primary 'historical act' of production itself. And since reproduction is not recognized as 'primary,' it cannot be seen to generate 'value" (Salleh 1994: 115). 
Figure 1 - Hidden Inputs of Households and Women into a Capitalist Commodity Chain

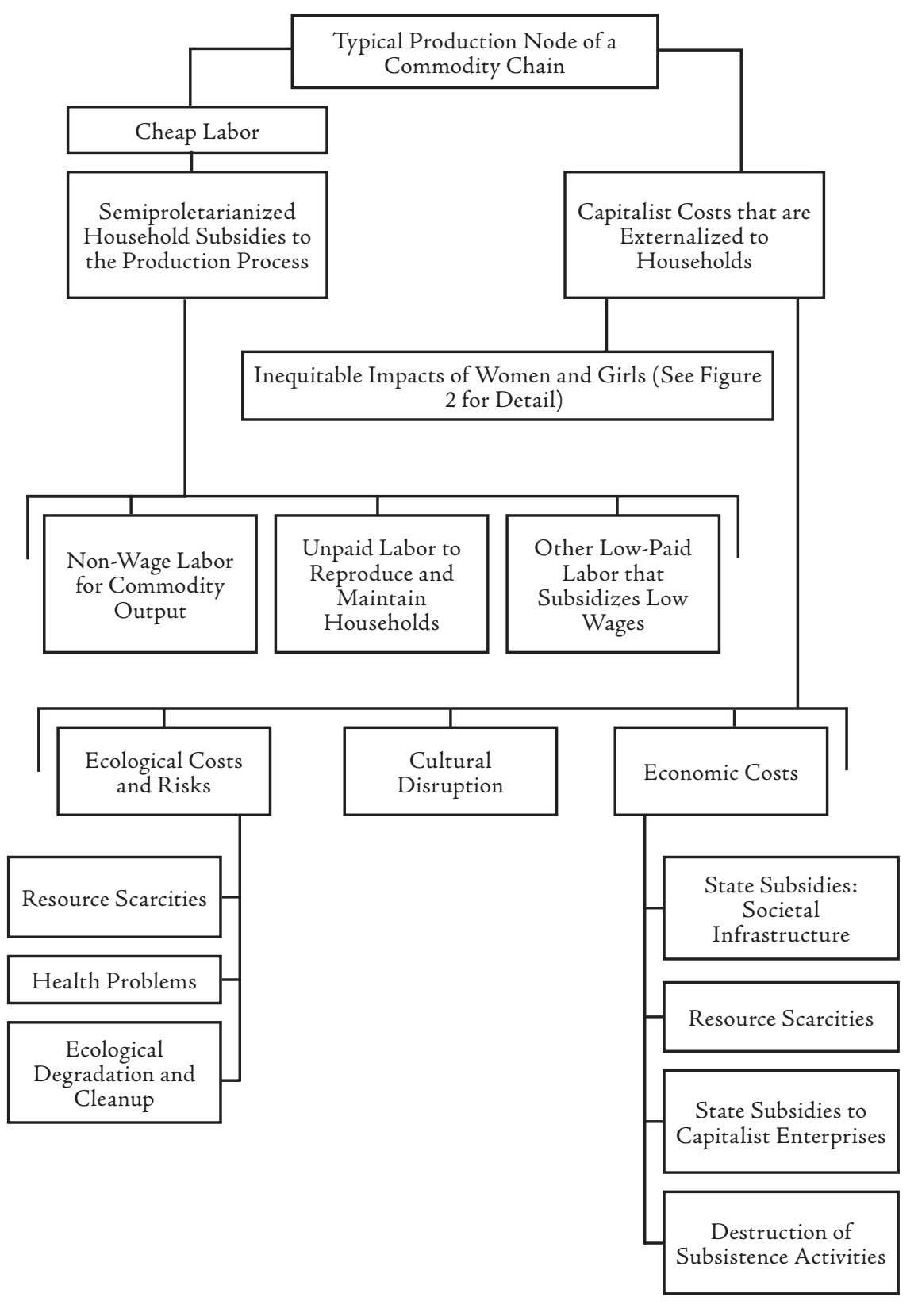

"shadow work" outside those formal capitalist structures in which labor is remunerated (von Werlhof 1985).

What the housewife produces in the family are not simply use-values but the commodity "labour-power" which the husband then can sell as a 'free' wage labourer in the labour market....the productivity of the housewife is the precondition for the productivity of the (male) wage labourer. The nuclear family, organized and protected by the state, is the social factory where this commodity "labour-power" is produced. Hence, the housewife and her labour are not outside of surplus value production, but constitute the very foundation upon which this process can get started. The housewife and her labour are, in other words, the basis of the process of capital accumulation (Mies 1986: 31).

Historically, the world-system has fed parasitically on "an army of nonwagelaborers, who are responsible for the (re)production of the necessary preconditions for wage-labor"(von Werlhof 1980: 41). This army of nonwage-laborers consists mostly of women (Emery 1986; Pelizzon 1999). During the late 20th century when the world-economy is experiencing intensified globalization, there are pressures on poor households to enlarge their boundaries and to self-exploit more (Nelson and Smith 1999). Thus, household nonwaged activities are actually increasing (Smith and Wallerstein, 1992: 9-16), and most of that labor is done by females (Hayashi 1998; Pelizzon 1999). Women's work is dominant in food production and processing, in responsibility for fuel, water, health care, child-rearing, sanitation and the entire range of so-called basic needs (Sen 1980). To accomplish that labor, most of the world's women draw heavily upon natural resources. In this way, the economic contributions of women remain structurally invisible; and the capitalist shifts to the worker's household and to the ecosystem a large portion of the actual costs of labor subsistence (Dunaway 1995; Instituto del Tercer Mundo 1994: 47).

There is a third more deeply hidden way in which women subsidize the commodity chains in which their households are situated. The subsistence inputs of women and households at one node may subsidize other nodes of the commodity chain. In effect, the commodity chain structures a network in which consumer and laborer households at higher nodes actually exploit households and women at lower nodes. Let me provide an historical example from my own research and then an example from the late twentieth century. In the U.S. Mountain South, small Appalachian plantations required slaves to generate half or more of their foodstuffs and all their shoes and clothing. That household subsistence production, primarily generated by women, made it possible for Appalachian masters to maximize their profits. Appalachian slave households reproduced, fed and clothed the surplus laborers exported by their owners. Through their forced migrations, those surplus slaves provided direct labor to produce the cotton that was exported to the world- 
economy. By externalizing to slave households the costs of their own reproduction and maintenance, mountain masters exported large quantities of food and clothing to provision the slaves who produced Lower South cotton. As a direct result of their hidden inputs into the cotton commodity chain, Appalachian slave households experienced chronic malnutrition, broken families, dangerously high fertility rates, and higher mortality rates. While mountain slave households subsisted on 70 percent of the needed survival nutrients, the Lower South slaves who consumed Appalachian surpluses were better fed and clothed, rarely were required to produce their own survival needs, and the women were pregnant only half as often. As a result, black Appalachian women died at a rate twice as high as that experienced by Lower South slave men, and mountain slave children were three times more likely to die than Lower South slave children (Dunaway, 2001: chapter 9). ${ }^{25}$

At the end of the late twentieth century, the women who manage the millions of households throughout the nodes of any commodity chain are divided internationally into producers and consumers. At the consumption end of a commodity chain, core women diminish their own household hardships because they are subsidized by the peripheral women whose low-paid and unpaid labor keeps prices low.

This relationship is structured in such a way that Third World women are objectively - not subjectively - linked to First World women through the commodities which the latter buy. This is not only a contradictory relationship, but also one in which the two actors on each side of the globe do not know anything of each other. The women in South and South-East Asia hardly know what they produce or for whom they make the things they make. On the other hand, the Western housewife is totally oblivious of the female labour, the working conditions, the wages, etc., under which the things which she buys are produced. She is only interested in getting these things as cheaply as possible.... the enslavement and exploitation of one set of women is the foundation of a qualitatively different type of enslavement of another set of women (Mies 1986: 121).

\section{WOMEN AND THE EXTERNALIZED COSTS OF COMMODITY CHAINS}

In addition to the failure of commodity chain analyses to investigate the hidden non-wage and unpaid inputs of women and households, there is another fundamental conceptual problem. Commodity chains have largely been constructed around the acquisition and organization of material inputs (Gereffi and Korzeniewicz 1994:2), a methodological decision which ignores the tendency

25. Similarly, impoverished antebellum Appalachian households subsidized the living conditions of Northeastern industrial laborers; see Dunaway (1996: chapter 10). of capitalists to externalize costs as much as possible (Wallerstein 1999). To maximize profits, capitalists must exploit as many "costless" social and natural conditions as possible. To put it differently, the capitalist mode of production structures and reshapes households in ways that minimize production costs by allowing extensive use of conditions external to the production process. Thus, capitalists shift to society, to the culture, to the ecosystem, and to human laborers most of the real costs of commodity production (see Figure 1). ${ }^{26}$ "Externalized costs are unseen and unpaid bills that are additional components of unequal exchange. They are part and parcel of normal capitalism, and they are to be found at every node/link of every commodity chain" (Wallerstein 1995).

Thus, semiproletarianized households subsidize commodity chains through their absorption of production costs that are externalized by capitalists (see Figure 2). Capitalism not only shifts to women the costs of reproducing the labor force and of subsidizing wage-earners. Capitalism also externalizes to women and girls greater costs and risks than are shifted to males. Because the inequalities are so stark, it is easy to be fooled into thinking that all peripheral men, women, and children experience the same degrees of immiseration. However, the world-system has structured "a modern form of patriarchal relations, in which women experience a social reality very different from their brothers in capital or labor" (Salleh 1994: 108-109). Consequently, peripheral men and women do not experience the same degrees of exclusion and poverty.

The double exploitation of women is based on the possibility of using their labor-power/sexuality as a human resource and their bodies as a natural resource....The difference in the exploitation of men and women consists in the fact that men normally are only exploited as human resource (labor-power/ sexuality) and not as if they were also a natural resource. Another difference, related to the first one, is that men are socially enabled to compensate for their exploitation (partly/totally?) by appropriating the labor-power/sexuality and bodies of women (von Werlhof 1980:40-41).

If we are to capture the workings of the household, therefore, we must recognize that there are two classes of people among the exploited: the doubly exploited (women) and those who are both exploited/exploiters (men).

To treat all peripheral households as though there are no gender differences in the experience of inequality is to ignore the worst effects of the world-system itself. Because women experience two levels of resource inequality (outside and within the household)

26. For a chart of social and cultural costs that are externalized by capitalism, see O'Connor (1994: 102-103). 
Figure 2 - The Inequitable Impacts of Capitalist Commodity Chains on Women and Girls

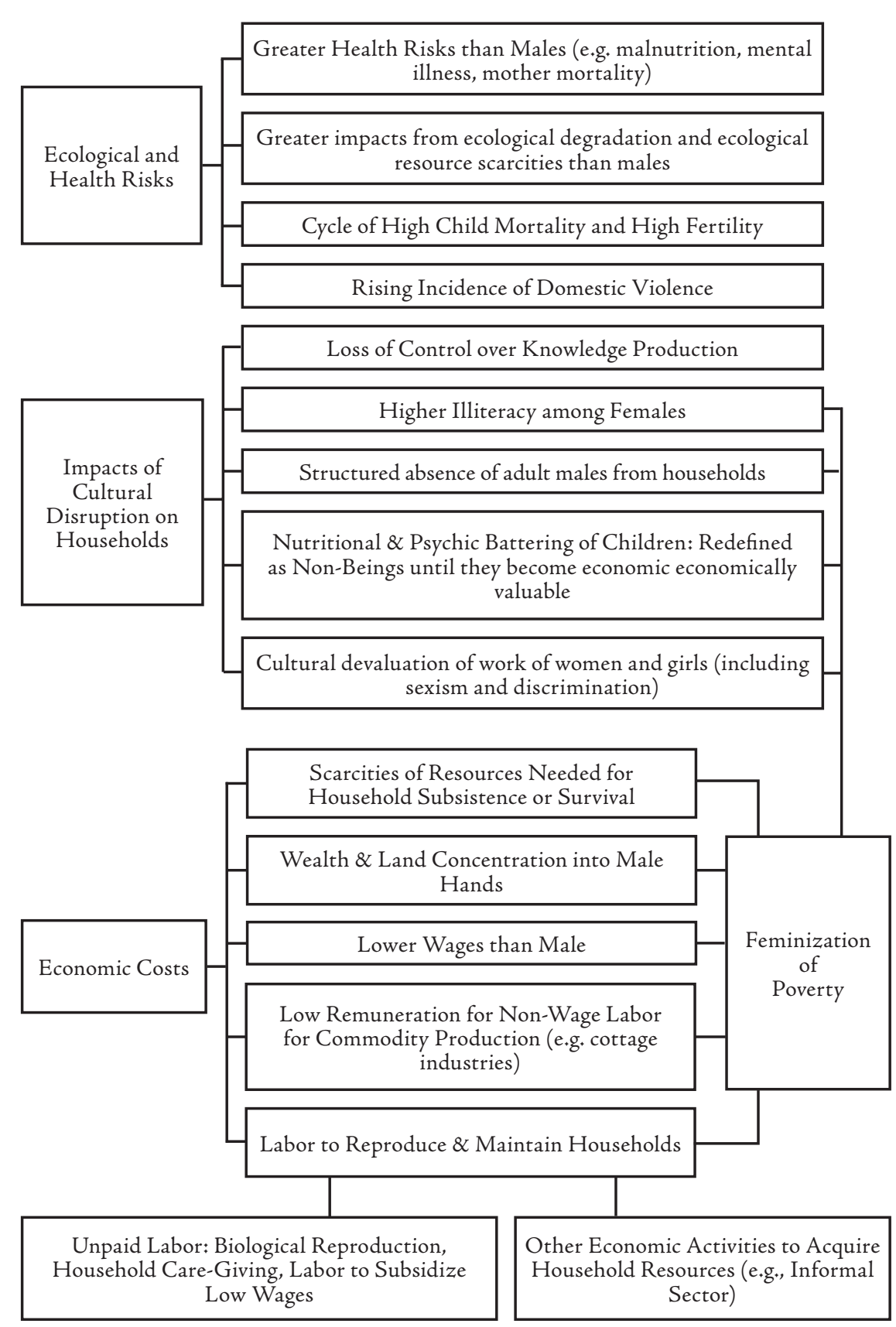

and because capitalism increases female subordination (outside and within the household), poverty is disproportionately felt by the world's women (Smith, Collins, Hopkins, and Muhammad, 1988: 28). Global trends of the late 20th century demonstrate their double exploitation. In every part of the world, women control very little of the wealth, even though they work longer hours than men. More than 70 percent of the world's illiterate adults are women. The world-system is currently structuring a vast international sex industry, and girls are targeted as the human resources to be exploited (Mies 1986: 137-42). In addition to these health and ecological risks, capitalism externalizes to women the negative side-effects of cultural change and disruption. Domestic violence increases dramatically as manufacturing and extractive industries enter new zones, and females are almost always the victims. The world-system has always structured the absence of males from poor households (Mies 1986), so there is an increasing trend toward female-headed households and feminization of poverty all over the world (United Nations 1999).

Global ecological stresses pose different crises for people according to their ethnic group, social class, sex, or age (Merchant 1992; Stephens 1994). Women are disproportionately endangered by the ecological degradation that accompanies capitalist development, and they are the household members who must contribute the labor needed to care for those made ill by environmental risks or resource depletion (Warren 1997: 8-9). Worldwide, resource scarcities impact women much more severely than men (Shiva 1988: 9). Water scarcity, desertification, deforestation, land degradation, and coastal pollution are forms of resource depletion that pose special hardships for women. Malnutrition is the most fundamental act of environmental sexism that is inflicted by the capitalist world-system upon women and girls. Half of all Third World children die before age ten. Females are disproportionately represented among those deaths because poor families allocate more of their scarce food resources and safe water to boys (United Nations 1999). Capitalism also externalizes to females the costs (e.g., the nutritional battering of children) associated with high fertility rates that follow high child mortality in about one-third of all peripheral countries (Ward 1985; Scheper-Hughes 1991).

The modern world-system has institutionalized the cultural devaluation of the work of women and girls. "Sexism was the relegation of women to the realm of non-productive labor, doubly humiliating in that the actual labor required of them was if anything intensified, and in that productive labor became in the capitalist world-economy, for the first time in human history, the basis for the legitimation of privilege." (Wallerstein 1983: 103). Consequently, institutionalized sexism makes possible reproduction of the work-force at the most profitable levels for capitalists. Gender discrimination provides an in-built training mechanism for the work-force, ensuring that a large part of the socialization in occupational tasks will be done within the framework of households and not at the expense of employers (Waller- 
stein $1984: 177)$. Consequently, integration into capitalist commodity chains brings destructive economic results for women. Historically and currently, women have been targeted for the dirtiest, most back-breaking aspects of the capitalist production process (Dunaway 1995), while higher-skilled, higher-paying artisan jobs have been reserved for males (Hayashi 1998; Pelizzon 1999). In the face of capitalist expansion, Third World women lose artisan jobs and local markets to imports and to commercialized agriculture (Mies, Bennhold-Thomsen, and von Werlhof 1988). Multinational corporations control the commodity chains that are initiating these economic changes, and these global conglomerates are externalizing major ecological costs to peripheral women. Females are entering the labor forces of multinational corporations faster than adult males, and this is a trend expected to continue into the 21 st century. To keep production costs low, multinationals are breaking the bodies of Third World girls and young women at an alarming rate. By eliminating safety equipment and sanitary working conditions, corporations externalize to women and children the health costs of industrial injuries and disabilities, work-related diseases, and the higher incidence of birth defects and mother mortality due to exposure to chemicals and industrial waste. Yet most of these women live in countries with grossly inadequate medical systems (Madeley 1999; Barndt 1999).

Over the historical existence of the modern world-system, capitalism has gradually reached deeper and deeper into the everyday lives of households. Because they remain less fully proletarianized than men, women are more intensively and more extensively exploited by capitalist commodity chains. When we take into account all paid, under-paid, and unpaid labor, it is clear that capitalism captures more of women's work time and extracts from them greater indirect subsidies than from males. What does capitalism extract from women that it does not take from men? In order to transform households into units that reproduce laborers and consumers, capitalism has commodified human reproduction; and it has reshaped and deformed child rearing and parenting (Mies, Bennhold-Thomsen, and von Werlhof 1988). In every historical era, the modern world-system has restructured households, repeatedly breaking families whose members (most often adult males) were removed by labor migrations (Boss 1993; Gisbert, Painter, and Quiton 1994; Grosfoguel 1997; Dunaway 2001). Capitalist commodity chains compete with households for limited ecological resources; and females contribute much more unpaid labor to those commodity chains than men (Wallerstein 1995:5-6). Over the life of peripheral women, their recruitment into and expulsion from waged labor is functionally tied to phases of the family life-cycle.

Women, by means of their work trajectories and strategies, supply labor for different processes of capital expansion and proletarianzation according to the family life cycle, a conditioning factor that does not pertain to men....the semiproletarianization of women-who in their character of unmarried daughters, wives and mothers, are differentially "expelled or retained" in the household they belong to-facilitate a different and generally higher paid labor opportunity for the husbands....It can be argued, therefore, that a kind of "functionality" of gender subordination exists for capital, not only through cheap reproduction of labor power by means of the housewife's nonremunerated domestic work, but also through the subproletarianization of the wives (Beneria and Roldan 1987: 102-103). ${ }^{27}$

Because it accumulates greater profits off the backs of women, the world-system does not seek to transform females into wage laborers. The system profits at maximal levels by semiproletarianizing women and by shifting to women and households most of the costs of commodity production (Hopkins and Wallerstein 1987; Shiva 1988). While women are semiproletarianized, they are also semi-domesticated-not able, then, to function predominantly within or outside their households. On the one hand, they are identified socially as housewives. On the other hand, they are "fully integrated in a world market oriented production system." According to Mies (1981: 493), "the social definition of women as housewives serves mainly the purpose of obscuring the true production relations and to consolidate their exploitation, ideologically and politically."

Women are not simply 'left behind' while men monopolize the new and more productive areas of the economy; they are in fact deliberately 'defined back' into the role of housewives. Only if women remain outside the formal sector and are socially defined as housewives can the double exploitation of their labor go on. Not only the big exporters, but also the husbands... are benefiting as nonproducers from [women's] ongoing subsistence production. The integration of women...into a world system of capital accumulation has not and will not transform them into free wage-labourers. It is precisely this fact-their not being free wage-labourers, but housewives - which makes capital accumulation possible. (Mies 1981: 500).

Clearly, females reproduce the world-system in ways that men cannot, yet capitalists remunerate them at much lower levels than males. If capitalists compensated women for all their externalized costs and unpaid labor, prices would be driven up so high that most commodities would not be competitive in the world-economy. Thus, the modern world-system has restructured gender into forms that permit maximal extraction of surpluses from households for the benefit of capitalist production. "It was exactly this (re) creation that gave the developments of world-capitalism its specific character and, along with historical dimensions, the fuel that would eventually and constantly (re)create world capitalism" (Smith 1993: 14).

27. As Beneria and Roldan (1987: 56-74) use the term, "subproletariat" is equivalent to Wallerstein's semiproletariat. 
CONCLUSION: BRINGING WOMEN TO THE CORE OF WORLD-SYSTEM ANALYSIS

Marginalization of gender issues by this perspective parallels the structural position of women in the world-system. At the ultimate periphery live women and girls in semiproletarianized households; and they comprise a majority of the world's poor. Moreover, there are two bare essentials without which the world-system cannot exist: (a) the reproductive capacity of the ecosystem to supply natural resources and (b) the reproductive capacity of women to supply the human laborers and consumers who make the system profitable. Those two realities alone should be enough to convince us all that we must bring women and households much more fully into the core research agenda of world-system analysis. Failure to prioritize women represents the greatest intellectual and political blunder of the world-system perspective. There can be no effective world-system analysis or praxis so long as women and households are introduced as an afterthought or ignored completely. Gender "is not just another variable to be thrown into analyses, but is an integral component of the world-system evolution. Focusing on gender points to new theoretical insights into the factors that shape group consciousness, into subtle forms of resistance to oppression, into the ways capital exploits extant cultural values, and into ways micro and macro social processes are linked" (Day and Hall 1991: 4).

Concepts like commodity chain and semiproletarianized housebold lay an important foundation for us to integrate the vantage points of women, but the perspective has not yet done that. With some revision, commodity chain research can be utilized to merge macrostructural trends with the micro-level, where we may discover the everyday lives on which the complex global system feeds. As Wallerstein (1986: 15) has pointed out, world-systems analysis was born as a moral and a political protest against the exploitation and inhumanity of the present world order. I am simply challenging proponents of the perspective to remember that political agenda and, thereby, to write morality tales that are more inclusive of a majority of the wretched of the earth. For every visible node in a commodity chain, there are many invisible links to households that are grounded in the super-exploited labor of women and girls. If, then, we engender commodity chains, we will discover that the tentacles of the world-system are entwined around the bodies of women. Every diagram of a commodity chain should remind us that consumers at the end point are devouring the lives and labor of multitudes who subsist off the invisible and unrewarded inputs of semiproletarianized women. And as we descend down the nodes of the commodity chain diagram, with every link we should call Her name, not the brand name of a product. For every link is embedded in the foundation we call Woman.

\section{REFERENCES}

Barndt, Deborah. 1999. Women Working the NAFTA Food Chain: Women, Food, and Globalization. Toronto: Second Story Press.

Beneria, Lourdes and Martha Roldan. 1987. The Crossroads of Class and Gender: Industrial Homework, Subcontracting, and Household Dynamics in Mexico City. Chicago: University of Chicago Press.

Bergquist, Charles, ed. 1984. Labor in the Capitalist World-Economy. Beverley Hills: Sage. Boss, Pauline G. 1993."The Experience of Immigration for the Mother Left Behind." Marriage and Family Review 19 (3/4): 365-78.

Braudel, Fernand. 1972. The Mediterranean and the Mediterranean World in the Age of Philip II. Translated by Sian Reynolds. New York: Harper and Row.

Braudel, Fernand. 1979. Afterthoughts on Material Civilization and Capitalism. Translated by Patricia Ranum. Baltimore: Johns Hopkins University Press.

Braudel, Fernand. 1981. Civilization and Capitalism, 15th to 18th Century: The Structures of Everyday Life. Translated by Sian Reynolds. New York: Harper and Row.

Bulbeck, Chilla. 1992."Third World Women: Dialogues with Western Feminism," Meinjin. 51 (2): 319-32.

Collins, Jane L. 1995. "Gender and Cheap Labor in Agriculture." Pp. 217-32 in Philip McMichael, ed., Food and Agrarian Orders in the World-Economy. Westport, CT: Greenwood Press.

Day, Catherine and Thomas D. Hall. 1991. "Are There Women in the World Economy?” PEWS News (Winter: 3-5).

Dickinson, Torry D. 1998. "Preparing to Understand Feminism in the 21st Century: Global Social Change, Women's Work, and Women's Movements." Journal of World-System Research http://jwsr.ucr.edu/ 4 (2): 96-111.

Dunaway, Wilma A. 1995."'The Disremembered' of the Antebellum South: A New Look at the Invisible Labor of Poor Women." Critical Sociology 21 (3): 89-106.

Dunaway, Wilma A. 1996. The First American Frontier: Transition to Capitalism in Southern Appalachia, 1700-1860. Chapel Hill: University of North Carolina Press.

Dunaway, Wilma A. 1997. "Rethinking Cherokee Acculturation: Women's Resistance to Agrarian Capitalism and Cultural Change, 1800-1838," American Indian Culture and Research Journal 21 (2): 155-92.

Dunaway, Wilma A. 2001. Slavery on Small Plantations: Forced Labor Migrations, Household Survival, and Reproductive Exploitation in the Mountain South. Cambridge: Cambridge University Press.

Elwert, Georg and Diana Wong. 1980."Subsistence Production and Commodity Production in the Third World: Review 3 (3): 501-22.

Emery, Mary E. 1986. "Women's Work and Working Women in the Development Process: The Experience of Women in Idaho." Ph.D. diss.: Rutgers University.

Feder, Ernest. 1980."The Odious Competition between Man and Animal over Agricultural Resources in the Underdeveloped Countries." Review 3 (3): 463-500.

Fox-Genovese, Elizabeth. 1983. "Antebellum Southern Households: A New Perspective on a Familiar Question." Review 7 (2): 181-214. 
Frobel, Folker. 1982."The Current Development of the World-Economy: Reproduction of Labor and Accumulation of Capital on a World Scale." Review 5 (4): 507-55.

Gereff, Gary and Miguel Korzeniewicz, eds. 1994. Commodity Chains and Global Capitalism. Westport, CT: Praeger.

Gisbert, Maria E., M. Painter, and M. Quiton. 1994."Gender Issues Associated with Labor Migration and Dependence on Off-Farm Income in Rural Bolivia." Human Organization 53 (2): 110-22.

Goldfrank, Walter, David Goodman, and Andrew Szasz, eds. 1999. Ecology and the World System. Westport, CT: Greenwood Press.

Grosfoguel, Ramon. 1997."Migration and Geopolitics in the Greater Antilles: From the Cold War to the Post-Cold War." Review 20 (1): 115-45.

Hall, Thomas. D., ed. World-Systems Reader: New Perspectives on Gender, Urbanism, Cultures, Indigenous peoples, and Ecology. Lanham, MD: Rowman and Littlefield, 2000.

Hayashi, Yoshie. 1998. “Women's Labor and Capitalist Development in Japan, 1600-1995: Historical Formation of Worker Segmentation and Peripheral Integration of Women's Labor." Ph.D. diss.: State University of New York at Binghamton.

Hopkins, Terence and Immanuel Wallerstein. 1986. "Commodity Chains in the WorldEconomy Prior to 1800." Review 10 (1): 157-70.

Hopkins, Terence and Immanuel Wallerstein. 1987."Capitalism and the Incorporation of New Zones into the World-Economy." Review 10 (3/4): 763-80.

Hopkins, Terence and Immanuel Wallerstein. 1994."Commodity Chains: Construct and Research." Pp. 17-20, 48-50 in G. Gereffi and M. Korzeniewicz, eds., Commodity Chains and Global Capitalism. Westport, CT: Praeger.

Instituto del Tercer Mundo. 1994. Third World Guide. Montevideo, Uruguay: Garamond Press.

Roberto P. Korzeniewicz and William F. Martin. 1994."The Global Distribution of Commodity Chains." Pp. 67-91 in G. Gereffi and M. Korzeniewicz, eds., Commodity Chains and Global Capitalism. Westport, CT: Praeger.

McCann, James. 1986. "Household Economy, Demography, and the 'Push Factor' in Northern Ethiopian History, 1916-35." Review 9 (3): 369-411.

McGuire, Randall H., Joan Smith, and William G. Martin. 1986. "Patterns of Household Structures and the World-Economy." Review 10 (1): 75-97.

McMichael, Philip. 1995. Food and Agrarian Orders in the World-Economy. Westport, CT: Greenwood Press.

Madeley, John. 1999. Big Business, Poor Peoples: The Impact of Transnational Corporations on the World's Poor. London: Zed Books.

Martin, William G. 1994."The World-System Perspective in Perspective: Assessing the Attempt to Move Beyond Nineteenth-Century Eurocentric Conceptions." Review $17(2): 145-86$.

Matthei, Linda M. and David A. Smith. 1996."Women, Households, and Transnational Migration Networks: The Garifuna and Global Economic restructuring." Pp. 133-50 in Roberto P. Korzeniewicz and William C. Smith, eds., Latin America in the World-Economy. Westport, CT: Greenwood Press.
The Double Register of History

Merchant, Carolyn. 1992. Radical Ecology: The Search for a Livable World. London: Routledge.

Meyers, Albert. 1983."Household, Labor Relations, and Reproductive Strategies among Small Cane Farmers in Jamaica." Review 7 (2): 181-214.

Micah, Raymond C. 1989."The Food Question in Ghana: Development Strategies and Policies." Review 12 (4): 457-501.

Mies, Maria. 1981. "Dynamics of Sexual Division of Labour and Capital Accumulation: Women Lace Workers of Narsapur." Economic and Political Weekly (March: 487-500).

Mies, Maria. 1982. The Lace Workers of Narsapur: Indian Housewives Produce for the World Market. London: Zed Books.

Mies, Maria. 1986. Patriarchy and Accumulation: Women in the International Division of Labor. London: Zed Books.

Mies, Maria, Veronika Bennhold-Thomsen, and Claudia von Werlhof. 1988. Women: The Last Colony. London: Zed Books.

Miller, Carol D. 1999."How Did Economic Development and Trade Affect Women's Share of the Labor Force in the 1980s?" Journal of World-System Research http://jwsr.ucr.edu/ 5(3):363-74.

Misra, Joya. 2000."Gender and the World System: Engaging the Feminist Literature on Development." Pp. 105-30 in Thomas D. Hall, ed., A World-System Reader: New Perspectives on Gender, Urbanism, Cultures, Indigenous Peoples, and Ecology. Boulder: Rowman and Littlefield.

Moghadam, Valentine M. 1999. “Gender and Globalization: Female Labor and Women's Mobilization." Journal of World-System Research http://jwsr.ucr.edu/ 5 (2): 301-14.

Moon, Paul. 1997."The Cross-Cultural Compatibility of Western Feminist Development Theory." Journal of World-System Research http://jwsr.ucr.edu/ 3 (2): 241-49.

Morrissey, Marietta. 1986. "Women's Work, Family Formation, and Reproduction among Caribbean Slaves." Review 9 (3): 339-68.

Mukras, Mohamed, J. O. Oucho, and M. Bemberger. 1985."Resource Mobilization and the Household Economy in Kenya." Canadian Journal of African Studies 19 (2): 409-21.

Nash, June and Patricia Fernandez-Kelly, eds. 1983. Women, Men, and the International Division of Labor. Albany: SUNY Press.

Nelson, Margaret K. and Joan Smith. 1999. Working Hard and Making Do: Surviving in Small Town America. Los Angeles: University of California Press.

O'Connor, Martin. (1994). Is Capitalism Sustainable? Political Economy and the Politics of Ecology. New York: Guilford Press.

Pelizzon, Sheila M. 1999."But Can She Spin? The Decline in the Social Standing of Women in the Transition from Feudalism to Capitalism." Ph.D. diss.: State University of New York at Binghamton.

Petrusewicz, Marta. 1987. "Wage-Earners but Not Proletarians." Review 10 (3): 471-503.

Phillips, Peter D. 1987. "Incorporation of the Caribbean, 1650-1700." Review 10 (3/4): 781-804. 
Polanyi, Karl. 1957. The Great Transformation: The Political and Economic Origins of Our Time. Boston: Beacon Press.

Portes, Alejandro. 1983."The Informal Sector: Definition, Controversy, and Relation to National Development." Review 7 (1): 151-74.

Quataert, Donald. 1988."Ottoman Handicrafts and Industry in the Age of Imperialism." Review 11 (2): 169-78.

Salleh, Ariel. 1994. "Nature, Woman, Labor, Capital: Living the Deepest Contradiction." Pp. 106-24 M. O'Connor, ed., Is Capitalism Sustainable? Political Economy and the Politics of Ecology. New York: Guilford Press.

Scheper-Hughes, Nancy. 1991. Death without Weeping: The Violence of Everyday Life in Brazil. Berkeley: University of California Press.

Sen, Gita. 1980."The Sexual Division of Labor and the Working-Class Family: Towards a Conceptual Synthesis of Class Relations and the Subsistence of Women." Review of Radical Political Economics 12 (2): 76-86.

Shiva, Vandana. 1988. Staying Alive: Women, Ecology and Development. St. Martin's Press.

Smith, David and Jozsef Borocz, eds. 1995. A New World Order? Global Transformations in the Late Twentieth Century. Westport, CT: Praeger.

Smith, Joan. 1993. "We Irish Women: Gender, History and the World-Economy." Review $16(1): 1-18$.

Smith, Joan and Immanuel Wallerstein, eds. 1992. Creating and Transforming Households: The Constraints of the World-Economy. Cambridge: Cambridge University Press.

Smith, Joan, Immanuel Wallerstein, and Hans-Dieter Evers. 1984. Households and the World-Economy. Sage.

Smith, Joan, Jane Collins, Terence K. Hopkins, and Akbar Muhammad, eds. 1988.Racism, Sexism, and the World-System. Westport, CT: Greenwood Press.

Stauth, Georg. 1983. "Capitalist Farming and Small Peasant Households in Egypt." Review 7 (2): 181-214.

Stephens, Sharon. 1994."Children and Environment: Local Worlds and Global Connections." Childhood 2 (1): 1-21.

Tailor, J. Edward and T.J. Watt. 1996."The Shadow Value of Migrant Remittances: Income and Inequality in a Household-Farm Economy." Journal of Development Studies. 32 (6): 899-912.

Thompson, Lanny. 1991."The Structures and Vicissitudes of Reproduction: Households in Mexico, 1876-1970." Review 14 (3): 403-36.

Truelove, Cynthia. 1987.“The Informal Sector Revisited: The Case of the Talleres Rurales Mini-Maquilas in Colombia." Pp. 95-111 in Richard Tardanico, ed., Crises in the Caribbean Basin. Beverley Hills: Sage.

Turner, Terisa E. and Craig S. Benjamin. 1995. "Not in Our Nature: The Male Deal and Corporate Solutions to the Debt-Nature Crisis." Review 18 (2): 209-60.

Ulshofer, Petra. 1983."Household and Enterprise: Towards a New Model of the Plantation." Review 7 (2): 181-214.
United Nations. 1999. 1999 Human Development Report. http://www.undp.org/hdro/ 99.htm

Vellenga, Dorothy. 1985."Women, Households, and Food Commodity Chains in Southern Ghana: Contradictions between the Search for Profit and the Struggle for Survival." Review 8 (3): 293-318.

von Werlhof, Claudia. 1980."Notes on the Relation between Sexuality and Economy." Review 4 (1): 32-42.

von Werlhof, Claudia. 1983."Production Relations without Wage Labor and Labor Division by Sex." Review 7 (2): 315-59.

von Werlhof, Claudia. 1985. "Why Peasants and Housewifes Don't Disappear in the Capitalist World-System." Paper delivered at the Annual Meeting of the American Sociological Association.

Wallerstein, Immanuel. 1976. "Semiperipheral Countries and the Contemporary World Crisis." Theory and Society 3 (Winter): 461-83.

Wallerstein, Immanuel. 1983. Historical Capitalism. London: Verso.

Wallerstein, Immanuel. 1984. The Politics of the World-Economy. Cambridge: Cambridge University Press.

Wallerstein, Immanuel. 1986."The World-System: Myths and Historical Insights." Pp. 15-24 in Edward W. Gondolf, I. M. Marcus, and J. P. Dougherty, eds., The Global Economy: Divergent Perspectives on Economic Change. Boulder: Westview Press.

Wallerstein, Immanuel. 1991. Unthinking Social Science: The Limits of Nineteenth-Century Paradigms. Cambridge: Polity Press.

Wallerstein, Immanuel. 1995."The Modern World-System and Evolution." Journal of World-System Research http://jwsr.ucr.edu/ 1(19).

Wallerstein, Immanuel. 1999."Ecology and Capitalist Costs of Production: No Exit." Pp. 3-12 in W.L. Goldfrank, David Goodman, and Andrew Szasz, eds., Ecology and the World System. Westport, CT: Greenwood Press.

Wallerstein, Immanuel and William G. Martin. 1979."Peripheralization of Southern Africa II: Changes in Household Structure and Labor-Force Formation." Review 3 (2): 193-207.

Wallerstein, Immanuel, William G. Martin, and Torry Dickinson. 1982."Household Structures and Production Processes: Preliminary Theses and Findings." Review 5(3): 437-58.

Ward, Kathryn. 1982."The Influence of the World Economic System on the Status of Women and Their Fertility Behavior." Ph.D. diss.: University of Iowa.

Ward, Kathryn. 1985."The Social Consequences of the World Economy System: The Economic Status of Women and Fertility." Review 8 (4): 561-94.

Ward, Kathryn, ed. 1990. Women Workers and Global Restructuring. Ithaca: Cornell University Press.

Ward, Kathryn. 1993. "Reconceptualizing World-system Theory to Include Women." Pp. 43-68 in Paula England, ed., Theory on Gender/Feminism on Theory. New York: Aldine. 
Waring, Marilyn. 1988. If Women Counted: A New Feminist Economics. San Francisco: Harper and Row.

Warren, Karen J. 1997. Ecofeminism: Women, Culture, Nature. Bloomington: Indiana University Press. 